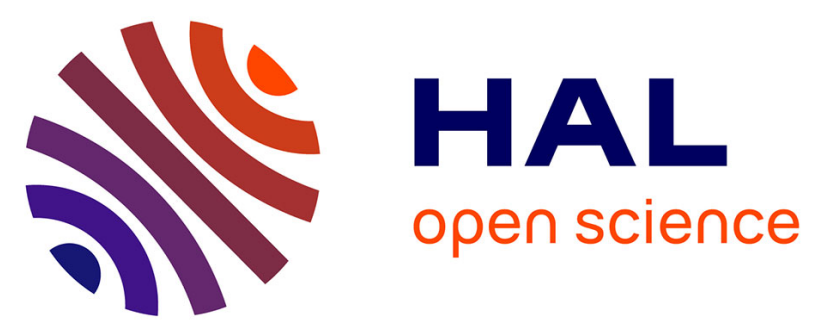

\title{
Childhood sexual abuse and adult sexual health among indigenous Kanak women and non-Kanak women of New Caledonia.
}

Christine Hamelin, Christine Salomon, Diane Cyr, Alice Guéguen, France Lert

\section{- To cite this version:}

Christine Hamelin, Christine Salomon, Diane Cyr, Alice Guéguen, France Lert. Childhood sexual abuse and adult sexual health among indigenous Kanak women and non-Kanak women of New Caledonia.. Child Abuse \& Neglect: The International Journal, 2010, 34 (9), pp.677-88. 10.1016/j.chiabu.2010.02.004 . inserm-00517658

\section{HAL Id: inserm-00517658 https://www.hal.inserm.fr/inserm-00517658}

Submitted on 15 Sep 2010

HAL is a multi-disciplinary open access archive for the deposit and dissemination of scientific research documents, whether they are published or not. The documents may come from teaching and research institutions in France or abroad, or from public or private research centers.
L'archive ouverte pluridisciplinaire HAL, est destinée au dépôt et à la diffusion de documents scientifiques de niveau recherche, publiés ou non, émanant des établissements d'enseignement et de recherche français ou étrangers, des laboratoires publics ou privés. 


\title{
Childhood sexual abuse and adult sexual health among indigenous Kanak women and non-Kanak women of New Caledonia.
}

Christine Hamelin, Christine Salomon, Diane Cyr, Alice Gueguen, France Lert

\begin{abstract}
:
Objectives. Few studies have addressed the long-term consequences of adverse childhood experiences among women in Oceania, in particular among indigenous women. This paper aims to report prevalences of childhood sexual abuse (CSA) and to asses the negative sexual health consequences in adulthood by comparing indigenous Kanak to non-Kanak women in New Caledonia.
\end{abstract}

Methods. Data come from a population survey on violence against women and health. Faceto-face interviews were conducted in 2002-2003 with adult women randomly selected from the electoral list. Separate models for Kanak $(n=329)$ and non-Kanak women $(n=426)$ were performed. Regression models adjusted for relevant socio-demographics factors were conducted to estimate the odds ratios for the associations between childhood sexual abuse and adult sexual health outcomes.

Results. A non significant difference between Kanak (11.8\%) and non-Kanak women (14.4\%) was found for the prevalence of CSA. Among Kanak women, CSA increases the risk of sexually transmitted infections, of non-desired sexual intercourse with an intimate partner and of experience of adult sexual violence. However, use of modern contraception as an adult was more frequent among CSA Kanak victims, as compared to other kanak women. Among non-Kanak women, only abortion appeared significantly associated with CSA.

Conclusions and practice implications. The findings show that in all ethnic communities of New Caledonia, a history of child sexual abuse is not rare among women. They also shed light on the long term consequences of CSA, suggesting that the effect of CSA may differ according to ethnic membership and subsequent social stratification and gender norms. 
Efforts to break the silence around violence against girls and establish a stronger foundation are required in New Caledonia. Prevention programs on violence against women and sexual health that take into account the cultural and social heterogeneity are needed.

\section{Introduction}

Violence against women is increasingly recognized as a major public health concern in Oceania. Studies relating to this issue, mostly carried out in countries of the region with populations of predominantly European origin, have revealed the impact of abuse suffered by girls and women on their sexual and reproductive health (Fanslow, Robinson, Crengle, \& Perese, 2007; Fergusson, Horwood, \& Lynskey, 1997; Secretariat of the Pacific Community, 2003; Taft, Watson, \& Lee, 2004). However, very few studies have described the long-term consequences of gender-based violence on indigenous women's sexual health, even though women within these communities have often been described as being at higher risk from abuse and in poorer health compared to other groups (Anderson et al., 2006; Bramley, Hebert, Tuzzio, \& Chassin, 2005; Salomon et al., 2003). This paper aims to analyze the associations between childhood sexual abuse (CSA) and adult sexual health among indigenous Kanak and non-Kanak women in New Caledonia.

Epidemiological studies have revealed an association between CSA and a long-lasting alteration in the capacity of victims to manage their fertility and sexuality. Studies focusing on sexual risk behavior in adult women are less concordant than those focusing on sexuality and reproductive health in adolescence (Littleton, Breitkopf, \& Berenson, 2007). Nevertheless, numerous other studies suggest that, alongwith factors linked to a context of both gender inequalities and globally unfavorable social and economic conditions, adult sexual and reproductive health also depends on adverse personal experiences in childhood, especially CSA. Indeed, CSA has been found to be associated with reduced condom use (Maman, 
Campbell, Sweat, \& Gielen, 2000; Molitor, Ruiz, Klausner, \& McFarland, 2000), less contraceptive use (Heise, Ellsberg, \& Gottmoeller, 2002), unintended pregnancy (Dietz et al., 1999; Steel \& Herlitz, 2005), abortion (Russo \& Denious, 2001; Wingood \& DiClemente, 1997) and sexually transmitted infections (STIs) (Hillis, Anda, Felitti, Nordenberg, \& Marchbanks, 2000; Petrak, Byrne, \& Baker, 2000). Abused women were also found to be at significantly higher risk of experiencing dissatisfaction in their sex lives and of presenting sexual difficulties in adulthood (Loeb et al., 2002; Mullen, Martin, Anderson, Romans, \& Herbison, 1996). Finally, early sexual abuse has been found to be a major risk factor for sexual assaults occurring in adult life and for abuse suffered from partners (Fergusson et al., 1997; Fleming, Mullen, Sibthorpe, \& Bammer, 1999; Steel \& Herlitz, 2005).

Among indigenous women, although the association between early sexual violence and heavy alcohol use has been investigated (Hamelin et al., 2009; Koss et al., 2003; Kunitz, Levy, McCloskey, \& Gabriel, 1998; Libby et al., 2004), very few studies have focused on sexual health indicators linked to childhood sexual abuse. Work carried out by Young and Katz (1998) in Canada, made the distinction between aboriginal and non-aboriginal women. In both groups, a history of sexual abuse was associated with an increase in the probability of STIs, sexual intercourse before the age of 12 years, and multiple sexual partners. While no association was observed with the conjugal or social situation of indigenous women, divorce or separation from a partner, as well as unemployment was associated with a previous history of sexual abuse in non-indigenous women. Yuan, Koss, Polacca, and Goldman (2006) studied physical assault and rape in adults from six U.S. Native tribes. They found that, as in the general population, childhood victimization was a predictor, whereas other predictors (e.g., level of tribal affiliation) were group specific.

New Caledonia is still a French ruled country, where the indigenous Kanak population is neither an overwhelming majority, as it is the case in the neighboring Melanesian states, nor 
a small minority as in Australia and New Zealand. The Kanaks represent $44 \%$ of the total population of 230000 inhabitants while Europeans (i.e. born in France or of European descent) account for 34\%, Polynesians 12\% (Wallisians and Futunians, and Tahitians), Asians $5 \%$ and persons from another community 5\% (Institut Territorial de la Statistique et des Etudes Economiques, 2001). In the 1980s, a nationalist rebellion for Kanak independence forced concessions from France and a process of re-balance of power in favor of the Kanak community (Matignon Accords, 1989 \& Nouméa Accord, 1998). The political and economic transformations that have taken place since then have led to increasing social heterogeneity within the Kanak community and have fostered significant changes for women: consolidation of a female urban population, increased level of girls' education, subsequent better access to employment and opportunity to earn a personal income, and implementation of gender parity in politics (Berman, 2005; Hamelin, 2000; Salaün, 2009). However, these major ongoing changes are not sufficient to counterbalance more than 150 years of colonial domination. Significant socioeconomic inequalities persist today. The Kanak population, who lives mainly in rural areas and islands, still holds a socioeconomically disadvantaged position in New Caledonian society. The 2004 census indicated that in the Northern Province and in the Loyalty Islands, where Kanaks are the overwhelming majority, the proportion of women aged 14 and over with no diploma was respectively $56 \%$ and $63 \%$. In the Southern Province, which is home to a mainly non-Kanak population, this proportion was 32\% (Institut de la statistique et des études économiques, 2007).

The non-Kanak population resides mostly in the Noumea metropolitan area but is quite heterogeneous regarding socio-economic characteristics and ethnicity. It is composed of successive migration waves, from the initial French convicts and settlers, and from the descendants of the Oceanian and Asian labor trade in the $19^{\text {th }}$ and first part of the $20^{\text {th }}$ century to more recent immigration from Polynesia and France (Merle, 1995). The Europeans, 
particularly wealthy French expatriates, have the highest position in terms of education, employment, and economic resources. The Polynesian and Asian inhabitants are well represented in certain segments of the local economy (as construction workers or small entrepreneurs for example), though their socio-economic position is lower than the Europeans'.

Although there is a certain amount of cultural mixing between the different communities several distinct cultural contexts and sets of social features exist. In particular, male domination remains a central element of gender relations among Kanaks. This is mostly evident in the division of daily activities, and the confining of women within the domestic sphere and obligatory maternity, as well as in obstacles faced by women wishing to escape an unhappy union, since divorce is almost impossible in Kanak rules and separating from a partner means leaving the children with him. These patterns, the value placed on reproduction and the license previously given to men to appropriate women's reproductive capacities through marriage and to impose discipline, as well as the scale of gender violence, all contribute to explain the narrow margins within which Kanak women can negotiate their sexuality (Berman, 2006; Salomon, 1998; Salomon, 2002).

Prior to the present study (2002), only data from police, criminal justice or women's organisations were available regarding CSA without any information on ethnicity. Prison records indicated that among male inmates, $15.9 \%$ were sentenced for violence against adults or minors and 39\% for rape or other forms of sexual assault (Guillonneau \& Kensey 1999). In 2002, in a total population of 200000,200 sexual assaults and rapes of minors were reported to law enforcement officials (Les Nouvelles Calédoniennes July 1, 2003). The same year, two thirds of the victims seeking help from "SOS Sexual Violence", an association helping victims of abuse, were minors (Les Nouvelles Calédoniennes July 1, 2003). However, because 
childhood sexual abuses are rarely denounced, such data from administrative or associative sources largely underestimated CSA rates.

To date, reproductive and sexual health has not been well-documented in New Caledonia and data on the ethnic community are even rarer. An existing system monitoring STIs, providing underestimated figures, nevertheless indicates an average annual incidence rate between 1997 and 2007 of 30 per 10000 inhabitants, 103.4 per 10000 in the $20-24$ years age group. The average incidence appeared to be five times higher in women compared to men (Direction des Affaires Sanitaires et Sociales, 2007). The scarce ethnic data confirm the existence of strong inequalities. Indeed, one survey conducted in 1999 indicated a significant difference between communities in the frequency of pregnancies without medical follow-up, with Kanak women showing the highest rate (25.7\%) and European and Asian women showing the lowest (4.4\%) (Barny, 2001). In addition, the number of Kanak women declaring their last pregnancy as unwanted is double that of European women (32\% versus $16 \%)$ even though the rate of abortion does not differ significantly between communities (Salomon et al., 2003).

The present analysis examines the association between early experiences of sexual abuse and adult sexual health among both Kanak women and non-Kanak women. Such a comparative perpective allows examining whether or not CSA is associated with adult sexual health in New Caledonia irrespective of ethnic group membership and other sociodemographic characteristics. Thus, it affords the opportunity to explore whether poor sexual health indicators among adult Kanak women might be linked to exposure to sexual abuse during childhood. 


\section{Methods}

\section{Participants and Procedure}

We used data obtained from a general population survey conducted between November 2002 and August 2003 in New Caledonia among women aged 18-54. The sample was drawn from the electoral rolls where most New Caledonian women are registered (88.2\% in 2002 in this age group), due to the political issues surrounding a self-determination referendum expected in 2014. Sampling from electoral rolls was stratified by age to better reflect the age structure of the New-Caledonian population. The sampling method resulted in all subjects having an equal weight of 1 . To be sure of obtaining around 1000 respondents, we drew an age-stratified sample of 4000 women at random. These 4000 subjects served as a pool from which women were drawn in successive waves to be contacted, until the required number of interviewees was reached. In all, 1679 women were drawn from the pool of 4000 for interviewers to contact. A letter was sent to these 1679 women to announce that an interviewer would soon contact them either by phone or directly at home. The letter clearly stated their right to decline the interview, to subsequently change their mind before or during the interview and to access and rectify the data. This letter presented the survey as a study on the living conditions and security of New Caledonian women and described the questions as related to childhood and adolescence experiences and to current family life. Violence, including childhood sexual abuse, was not explicitly identified as one of the survey topics. A total of 580 women could not be located or had moved outside the area of residence registered on the electoral rolls. Of the 1099 successfully contacted, 1012 (92.1\%) agreed to participate. Of the women who did not participate, $5 \%$ refused to take part and $2.9 \%$ missed their appointments. Less than $1 \%$ cut the interview short, mostly before the questions on violence were asked. Only the women of reproductive age (aged from 18 to 49 years) and sexually 
active during the preceding twelve months were included in the present analyses (Kanak women $n=329$, non-Kanak women $n=436$ ).

Data were collected anonymously using a standardized questionnaire in face-to-face interviews that lasted an average of one hour. The interviews were conducted by 15 female interviewers belonging to the various ethnic communities of New Caledonia (Kanak, European, Polynesian, and Asian) and trained by the two main investigators of the study. Women were interviewed in complete privacy, for the main part in their homes or in another place chosen by them. The first part of the questionnaire concerned women's social and demographic situation. Ethnic classification was based on self-definition, according to the categories used in the 1996 New Caledonia Census (Melanesian, European, Wallisian or Futunian, Tahitian, Indonesian, Vietnamese, Other). In the present analysis the Kanak group consisted of women who identified themselves as Melanesian while the non-Kanak group aggregated women who identified themselves as European, Wallisian or Futunian, Tahitian, Indonesian, Vietnamese or from another community. The second part of the interview concerned women's health, including sexual and reproductive health. A third part enquired about any abuse suffered over the last 12 months leading up to the interview. Finally, the last part related to any physical abuse suffered from the age of 15 years onwards and sexual abuse suffered during childhood and later. All women who experienced sexual abuse were asked to identify the perpetrator of the single event or of the first event if repeated abuse was reported. The study was approved by the French data protection authority (Commission Nationale Informatique et Libertés). It complied with the ethical guidelines for confidentiality formulated by the WHO (Watts, Heise, Ellsberg, \& Garcia-Moreno, 2001). 


\section{Measures}

\section{Childhood sexual abuse}

Childhood sexual abuse was assessed using two questions about lifetime sexual abuse: "During your life, has anyone ever fondled you sexually when you did not want to, or unsuccessfully tried to have sexual intercourse with you?", "During your life, has anyone ever forced you to have sexual intercourse against your will?". In both cases, women were asked their age at the time of the event or at the first and last time when repeated abuse was reported. Thus, the indicator of childhood sexual abuse was defined as having experienced sexual fondling, attempted rape or rape, one or more times before the age of 15 . The age of 15 was used as cutpoint because of differences in the characteristics of abuse before age 15 and abuse at age 15 and older. In addition, the age of 15 was the upper limit often used in international studies to define sexual abuse experienced during childhood (Garcia-Moreno, Jansen, Ellsberg, Heise, \& Watts, 2005).

\section{Sexual health indicators}

Five indicators of sexual health were examined:

Regarding the use of contraception, women who answered yes to the question "Currently, do you use a method of contraception to avoid being pregnant?" were asked to specify the method. Women using no contraception or who had resorted to traditional methods (withdrawal, temperature, local plant remedies) were compared to those using modern contraception (contraceptive pill, intrauterine device, condom, implant, tubal ligation). A total of 216 (109 Kanak, and 107 non-Kanak) women were excluded from analyses examining the association between CSA and contraception because they indicated that they were infertile, pregnant, or wanted to become pregnant and thus were not in need of contraception. 
Women who reported ever having been pregnant were questioned about whether and when they had an abortion. Women who declared an abortion during the last five years were compared to the others.

The variable STIs identified those women who answered yes to the question: "During the last 12 months, did you suffer from a sexually transmissible disease?"

Women were asked how often they had had undesired sexual intercourse in the last twelve months with their intimate partner. The exact wording of the survey question was: "During the last 12 months, did you accept sexual intercourse without really wanting it?" Answers were split into two categories: often versus never, rarely or sometimes.

Several questions were used to document adult sexual violence, depending on the perpetrator. Two questions assessed intimate parter/ex-partner's sexual violence: “During the last 12 months, did your partner/ex-partner force you to have sexual intercourse when you did not want to?" and "During the last 12 months, did your partner/ex-partner force you to do or to submit to sexual acts when you did not want to?” Regarding close relatives, acquaintances and strangers two questions were asked for each: "During the last 12 months, did a close relative (acquaintances/stranger) try unsuccessfully to have sexual intercourse with you, or to force you to engage in sexual acts against your will?" and "During the last 12 months, did a relative (acquaintance/stranger) force you to have sexual intercourse against your will?". Adult sexual violence covered any of the situations described above from any perpetrator (intimate partner /ex-partner, close relative, acquaintance and stranger).

\section{Statistical analysis}

We studied the associations between CSA and indicators of adult sexual health, adjusting for age and marital status, both of which are variables directly associated with sexual behavior. Age was divided into three classes: 18-25 years, 26-37 years and 38-49 
years. Three categories were used to define marital status: married or living together as a couple, being in a stable relationship (for at least 6 months) though not living together, and no stable relationship over the last year. Women's sexual health appears also influenced by socioeconomic and educational factors (Wellings et al., 2006). Educational level and personal income level were considered and included in logistic regression models. The highest level of educational achievement was divided into 3 categories: none or elementary school qualification, below baccalaureate (vocational qualifications at the end of junior high), Baccalaureate or higher, the Baccalaureate being the diploma obtained upon completing the high school curriculum. In New Caledonia, the social value of this qualification has historically been and remains important, and is an advantage for entering the paid workforce. Personal income was divided into 2 categories taking as a cut point half the legal minimum wage: 335 Euros/month or less versus more than 335 Euros/month. The question on economic resources included revenue from employment, benefits and allowances awarded by the state, and money earned selling fish or cultivated products at the road side or at the market. Occupational status was classified into 3 categories : employed, housewive or subsistence farmer, and unemployed, student or other.

We built separate models for Kanak and non-Kanak women. Descriptive analyses were performed to obtain information regarding the socio-demographic characteristics of both sub-samples. Bivariate Chi-square analyses were conducted to examine differences between Kanak and non-Kanak women in prevalence rates of CSA and adult sexual outcomes. No use of modern contraception, abortion, STIs, undesired sexual intercourse and adult sexual violence were taken as dependent variables. Separate logistic regression models assessed the association between CSA and each indicator of adult sexual health after adjusting for all covariates in Kanak and non-Kanak group. Occupational status was not included in 
multivariate models because of colinearity with personal income. All analyses were performed using Statistical Analysis Software (SAS v9.1, SAS Institute Inc, Cary, NC, USA).

\section{Results}

Socio-demographic characteristics

The average age of the Kanak women sub-sample was 32 years (SD 8.76); it was 33.5 years (SD 8.24) for the non-Kanak sub-sample. In both groups, most women were in a stable relationship but Kanak women were more likely not to live with their partner (Table 1). The groups differed substantially in terms of educational level and economic resources. Only $10.9 \%$ of Kanak women obtained the Baccalaureate compared with more than $40 \%$ of nonKanak women. Over half of the Kanak women had no personal income or were earning a very small personal income. The proportion of non-Kanak women in the same situation was $27.3 \%$. Regarding occupational status, $46.5 \%$ of Kanak women were employed $(68.3 \%$ among non-Kanak women), 39.8\% declared being housewives or subsistance farmers (18.6\% among non-Kanak women), $13.9 \%$ were unemployed, student or in another situation (12.6\% among non-Kanak women). 
Table 1

Socio-demographic characteristics of Kanak and non-Kanak women

\begin{tabular}{|c|c|c|c|c|c|}
\hline & \multicolumn{2}{|c|}{$\begin{array}{c}\text { Kanak women } \\
(n=329)\end{array}$} & \multicolumn{2}{|c|}{$\begin{array}{c}\text { non-Kanak women } \\
(n=436)\end{array}$} & \multirow[b]{2}{*}{$p^{a}$} \\
\hline & $n$ & $(\%)$ & $n$ & $(\%)$ & \\
\hline \multicolumn{6}{|l|}{ Age } \\
\hline $18-25$ years & 99 & 30.1 & 82 & 18.8 & \multirow{3}{*}{.0006} \\
\hline 26-37 years & 125 & 38.0 & 294 & 48.6 & \\
\hline $38-49$ years & 105 & 31.9 & 436 & 32.6 & \\
\hline \multicolumn{6}{|l|}{ Marital status } \\
\hline Married or cohabiting & 234 & 71.1 & 349 & 80.0 & \multirow{3}{*}{.0001} \\
\hline Stable partner, not cohabiting & 71 & 21.6 & 46 & 10.6 & \\
\hline year & 24 & 7.3 & 41 & 9.4 & \\
\hline \multicolumn{6}{|l|}{ Educational level } \\
\hline None or Elementary & 170 & 51.7 & 113 & 25.9 & \multirow{3}{*}{$<.0001$} \\
\hline$<$ baccalaureate & 123 & 37.4 & 146 & 33.5 & \\
\hline Baccalaureate or higher & 36 & 10.9 & 177 & 40.6 & \\
\hline \multicolumn{6}{|l|}{ Personal Income } \\
\hline$\leq 335$ Euros/month & 188 & 57.1 & 119 & 27.3 & \multirow[b]{2}{*}{$<.0001$} \\
\hline > 335 Euros/month & 141 & 42.9 & 317 & 72.7 & \\
\hline \multicolumn{6}{|l|}{ Occupational status } \\
\hline Employed & 153 & 46.5 & 298 & 68.3 & \multirow{3}{*}{$<.0001$} \\
\hline $\begin{array}{l}\text { Housewive or subsistence } \\
\text { farmer }\end{array}$ & 131 & 39.8 & 81 & 18.6 & \\
\hline Unemployed, student, other & 45 & 13.9 & 57 & 12.6 & \\
\hline
\end{tabular}

Prevalence and characteristics of Childhood Sexual Abuse

A non significant difference between Kanak and non-Kanak women was found for CSA, the prevalence being respectively 11.8 and $14.4 \%$ (Table 2). Among women having suffered from sexual abuse, $38.5 \%$ of Kanaks and $22.2 \%$ of non-Kanaks had experienced rape. In both groups, most victims knew their aggressor. Nevertheless, the proportion of close relatives among the agressors appeared higher in Kanak (66.7\%) than in non-Kanak women (42.8\%). A non significant difference between Kanak and non-Kanak women was found for the frequency of abuse. 
Table 2

Prevalence of childhood sexual abuse and sexual health outcomes in adulthood among Kanak and nonKanak women

\begin{tabular}{|c|c|c|c|c|c|}
\hline & \multicolumn{2}{|c|}{$\begin{array}{l}\text { Kanak women } \\
\quad(n=329)\end{array}$} & \multicolumn{2}{|c|}{$\begin{array}{c}\text { non-Kanak } \\
\text { women } \\
(n=436) \\
\end{array}$} & \multirow[b]{2}{*}{$p^{a}$} \\
\hline & $n$ & $(\%)$ & $n$ & $(\%)$ & \\
\hline Childhood sexual abuse & 39 & 11.8 & 63 & 14.4 & 0.296 \\
\hline \multicolumn{6}{|l|}{ Type of abuse } \\
\hline Rape & 15 & 38.5 & 14 & 22.2 & 0.077 \\
\hline Sexual fondling & 24 & 61.5 & 49 & 77.8 & \\
\hline \multicolumn{6}{|l|}{ Perpetrator } \\
\hline Close relative & 26 & 66.7 & 27 & 42.8 & \\
\hline Acquaintance & 12 & 30.8 & 24 & 32.2 & 0.044 \\
\hline Stranger & 1 & 2.5 & 12 & 19.0 & \\
\hline \multicolumn{6}{|l|}{ Frequency of abuse } \\
\hline Once & 20 & 51.3 & 26 & 41.3 & 0.323 \\
\hline More than once & 19 & 48.7 & 37 & 58.7 & \\
\hline Failure to use modern contraception ${ }^{b}$ & 66 & 30.0 & 67 & 20.3 & .009 \\
\hline Abortion & 27 & 8.2 & 22 & 5.1 & 0.078 \\
\hline Sexually Transmitted Infection & 20 & 6.1 & 5 & 1.2 & $<.0001$ \\
\hline Undesired sexual intercourse & 104 & 31.6 & 77 & 17.7 & $<.0001$ \\
\hline Adult sexual violence & 61 & 18.5 & 17 & 3.9 & $<.0001$ \\
\hline
\end{tabular}

${ }^{a} \chi^{2}$ test

${ }^{\mathrm{b}}$ Women declared infertile and those pregnant or with a desire to be so at the time of interview were excluded from analyses on contraception ( $n=220$ for Kanak women, and $n=329$ for non-Kanak women)

\section{Prevalence of sexual health indicators in adulthood}

Failure to use modern contraception was more frequent among Kanak women than among non-Kanak women, while no significant difference between the two groups was observed for abortion (Table 2). Having been diagnosed for STIs in the last 12 months was more often reported by Kanak women compared to non-Kanak women (6.1\% versus $1.2 \%)$. Nearly one in three Kanak women reported regularly having undesired sexual intercourse with their intimate partner while this proportion was $17.7 \%$ among non-Kanaks. Finally, in 
the year leading up to the survey, $18.5 \%$ of Kanak women had suffered some form of sexual violence compared to $3.9 \%$ of non-Kanak women. In both groups, this was mainly reported as occurring within the couple.

\section{Association between CSA and sexual health indicators in adulthood}

Table 3 presents the results obtained from bivariate and multivariate analyses between these indicators and CSA in Kanak and non-Kanak women.

In Kanak women, failure to use modern contraception was less likely among women with a CSA history; Even though failure to use of modern contraception also correlated with age and personal income, its association with CSA did not change after adjustment for those two variables (Adjusted OR: 0.2, 95\% CI: 0.07-0.8). While abortion was associated with a higher educational level, no correlation with CSA was observed. Kanak women who had suffered CSA were more likely to declare a recent STI. The association remained significant and very strong when adjusted (Adjusted OR: 3.8, 95\% CI: 1.3-10.9). Regularly having undesired sexual intercourse with an intimate partner was found to be associated with CSA, age at the time of the survey and marital status. After adjusting for covariates, the association between CSA and non-desired sexual intercourse remained significant for this group and even increased (Adjusted OR: 3.4, 95\% CI: 1.6- 7.2). A strong relation was also found between CSA and experience of sexual violence in the 12 months leading up to the survey. The adjusted odds ratio for adult sexual violence was five times higher among Kanak women who had suffered CSA, compared to those who had not (Adjusted OR: 5.2, 95\% CI: 2.4-11.1).

Among non-Kanak women, failure to use modern contraception was strongly correlated with low education, poverty and unstable intimate relationships but not with CSA. A significant adjusted association between CSA and abortion was observed (Adjusted OR: 3.1, 95\% CI: 1.1-8.8). Abortion was also associated with a low level of education. Regarding 
STIs in this group, the number of cases was too small to allow for bivariate and multivariate analysis $(n=5)$. While no significant association was observed between undesired sexual intercourse and CSA, women with a low level of education were more likely to have had undesired sexual intercourse with an intimate partner compared with those who had a higher educational level. Finally, in bivariate analysis, adult sexual violence was associated with age and income but not with CSA. After adjusting for covariates, the odds-ratio for CSA increased from 1.9 to 2.6 but did not reach statistical significance. The adjusted odds-ratio for age decreased and was no longer statistically significant. Only women with low personal income were still at significant risk for adult sexual violence.

\section{Discussion}

The results obtained in the present study suggest that relationships between CSA and adult sexual health problems differ between indigenous women and other women in New Caledonia. With the exception of abortion, Kanak women's sexual and reproductive health is strongly associated with a history of childhood sexual abuse. Indeed, in this community, CSA considerably increases the risk of STIs, of non-desired sexual intercourse with an intimate partner and of experience of adult sexual violence, even after adjustment for potentially confounding variables (age, marital status, and educational and income level). But, whereas three outcomes - STIs, non-desired sexual intercourse and adult sexual violence - indicate an increased vulnerability associated with CSA, the fourth one - failure to use modern contraception displays a reverse association. In the non-Kanak group, only abortion appears significantly associated with CSA.

A number of limitations of this study have to be acknowledged. First, because of the low prevalence of adult sexual health problems among non-Kanak women, the sample size was not sufficient to detect an effect of CSA in this group. This was especially the case 
regarding the association between CSA and sexual violence experienced in adulthood (17 cases reported in 436 women). Although the OR of adult sexual violence was also elevated in this group (Adjusted OR: 2.6, 95\% CI: 0.7-9.0), the association was not statistically significant and the confidence interval was large. Secondly, the restricted size of the two subsamples did not allow us to take into account the characteristics of the early sexual abuse, which are known to influence long term health: age at onset of abuse, relationship to offender, duration and frequency of abuse, non-penetrative abuse or forced intercourse with penetration (Beitchman et al., 1992; Fleming et al., 1999; Parillo, Freeman, Collier, \& Young, 2001).

In addition, this retrospective study carried out among adult women revealed the associations, but not the causal pathway, between CSA and adult sexual health. Various factors not documented in this study such as psychiatric disorders (Steel \& Herlitz, 2005) or the characteristics of the partner (Testa, VanZile-Tamsen, \& Livingston, 2005), might be involved in the observed association between CSA and adult sexual health. The effects of potentially confounding factors could not be taken into account considering the limited data on family background and on other adverse childhood experiences, notably childhood physical and emotional abuse (Mullen et al., 1996). It has been shown that women exposed to CSA tend to have an earlier onset of consensual sexual intercourse with this, in turn, increasing risks of unprotected intercourse, multiple partnerships, and other forms of sexual risk taking later on (Fergusson et al., 1997). This association cannot be properly assessed in the present study: for some women the age at the first reported sexual experience corresponds to the age the CSA occurred. Thus, the first sexual intercourse reported may be the CSA itself. Additionally, we have to consider the possibility that sexual activity at the time of data collection was associated with prior victimization history, which would introduce a bias in an analysis restricted to sexually active women. Actually, in both groups, sexual activity during the last 12 months was not associated with childhood sexual abuse (Age-adjusted OR: 0.9, 
95\% CI: 0.4-1.9 for Kanak women, and age-adjusted OR: 06, 95\% CI: 0.3-1.3 for non-Kanak women).

To minimize under-reporting and to ease recollection and disclosure of early sexual abuse, the questions about CSA in our study were asked after those relating to the women's current living conditions and life history. Thus, trust gained during the interview might have facilitated answering such sensitive questions. But these techniques do not completely prevent under-reporting of CSA (Watts \& Zimmerman, 2002; Williams, Siegel, \& Pomeroy, 2000). This under-reporting could lead to underestimating the observed associations.

This study also has a number of strengths. It is the first one to document prevalence of childhood sexual abuse in the general female population in New Caledonia and to provide sexual health data according to ethnic membership. In non-Kanak women, all sexual health problems were correlated to a low social status (i.e. low personal income or low educationnal level). Conversely, among Kanak women, STIs, undesired sexual intercourse with a partner and adult sexual violence were found to be unrelated to socio-economic factors. This lack of assocation between socio-economic characteristics and sexual health outcomes may reflect quite a narrow variability in education and income level within the Kanak community. Because socioeconomic inequalities, ethnic divisions and disparities in health are tightly intertwined, Kanak women as a group are in the least favourable situation, in terms of social position, sexual heatlh and gender violence in adulthood. Thus, ethnicity still determines large differences regarding sexual health in New Caledonia today.

Despite this, the prevalence of sexual abuse during childhood was not found to significantly differ across the two groups in the study. This contrasts with the situation in neighboring Pacific countries, where higher frequencies were observed in indigenous minorities compared to the general population. The mean rate in Australia was 12\%, but information on community was not available (Australian Bureau of Statistics, 2006). 
However, the overexposure of Aboriginal girls to sexual abuse has often been stressed (P. Anderson \& Wild, 2007; Stanley, Kovacs, Tomison, \& Cripps, 2002). In New Zealand, according to the definition used by the WHO, $23.5 \%$ of urban women and $28.2 \%$ of rural women were sexually abused before the age of 15 years. In both urban and rural areas, rates were higher among Maori women (Fanslow et al., 2007).

In our study, the possibility of greater underreporting in Kanak women than in nonKanak women has to be considered. As shown in a previous article, older and rural Kanak women were found much more inclined than their younger and urban counterparts to find a justification for male physical and sexual violence (Salomon \& Hamelin, 2008). Consistently with this observation, older Kanak women reported CSA significantly less often than their younger counterparts $(6.7 \%$ in age $38-49,10.4 \%$ in age $26-37,19.2 \%$ in age $18-25, p=0.018)$ and rural Kanak women reported CSA significantly less often than their urban counterparts $(10.4 \%$ versus $21.4 \%, p=0.039)$. It is known that variations in reporting rates are more likely to reflect changes in social tolerance and agency practice than changes in the prevalence of violence (Bajos \& Bozon, 2008; Pereda, Guilera, Forns, \& Gomez-Benito, 2009). Such generational and residential differences were not recorded in the non-Kanak group in which the social process of rejection of gender violence, especially against young girls, seems to have been engaged for longer.

Even though the rate of CSA may not systematically vary between any two communities, the circumstances of this abuse, the level of tolerance or disapproval associated with it, and the effects of disclosure are susceptible to considerable variation, dependent on the socio-cultural context of each community, and thus influence the impact in adulthood in different ways (Loeb et al., 2002). The results of the present study highlight the consequences of early female sexual abuse in the indigenous Kanak community where gender violence in adulthood and women's sexual vulnerability are particularly widespread. The overexposure to 
adult sexual violence, especially from an intimate partner, among female victims of CSA has been documented by numerous studies carried out in different regions, including Oceania. In Australia, the probability of experiencing domestic abuse and rape in adulthood was twice as high in women who had suffered CSA compared to those who had not (Fleming et al., 1999). Similarly, in New Zealand, women reporting CSA were about twice as likely to have experienced sexual or physical abuse perpetrated by an intimate partner in the previous 12 months (Fanslow et al., 2007). Still, the association observed in Kanak women seems particularly strong, since those who suffered CSA were five times more likely to experience adult sexual violence than those who had not suffered CSA.

The strong association between CSA and STIs in Kanak women points to an increased likelihood of sexual risk behaviors in adult Kanak victims of CSA. This finding suggests that women who have been sexually abused in childhood encounter more difficulties negotiating the use of condoms by male partners in an effort to protect themselves (Hillis et al., 2000; Petrak et al., 2000). In New Caledonia, where the margins within which Kanak women can negotiate their sexuality are narrow and where condom use is viewed as a "male business" especially in rural regions and among the less educated (Bougerol \& Salomon, 1998), female child sexual abuse appears as an additional burden in regard to decision-making and management of sexuality later on.

The results also show that modern contraceptive use was less frequent among Kanak women than among non-Kanak women. The lower level of modern contraceptive use in Kanak women could be a consequence of a lack of autonomy in their reproductive lives due to strong gender inequalities. It might also be related to poor accessibility of medical facilities as shown by data on delayed onset of prenatal care among Kanak women (Barny, 2001). The positive association between CSA and the use of modern contraception in the Kanak group is thus all the more unexpected, especially as this association was not found in the non-Kanak 
group. Among Kanak women, modern contraceptive methods have only become widespread over the last 15 years and social norms require women to give birth to several children. To make sure that the observed association was not linked to a confounding effect (already having children), complementary analysis was carried adjusting for the number of children (0 versus 1 or more). The known relationship between the use of contraception and the number of children was also observed here (OR: $2.8,95 \%$ CI: 1.2-6.7) but did not significantly modify the association between CSA and contraception use (Adjusted OR: 0.3, 95\% CI: 0.070.9). The small size of the sub-samples did not allow us to conduct separate analyses for each contraception method. Of Kanak women using modern contraception, 50.6\% were on the contraceptive pill, $28 \%$ had an intrauterine device, $13 \%$ used condoms, and $8.4 \%$ another method (implant or tubal ligation). Of non-Kanak women using modern contraception, $67.6 \%$ were on the contraceptive pill, $22.9 \%$ had an intrauterine device, $3.8 \%$ used condoms and $5.7 \%$ another method. Thus, in both groups, contraception mostly captured the use of the pill or of an intrauterine device.

To our knowledge, little research investigates directly the association between sexual violence and contraception use. Some studies have shown reduced contraception use among women having suffered CSA compared to others (Boyer \& Fine, 1992; Heise et al., 2002). Inconsistantly, among both indigenous and non-indigenous women in Canada, no association has been found between a history of sexual abuse and the use of oral contraception. However, in the non-indigenous group, the use of an intrauterine device was significantly more frequent among those who had suffered sexual abuse compared to those who had not. This association has not been found among indigenous women (Young \& Katz, 1998).

The relationship between sexual violence and contraception appears to be particularly complex, all the more so in a society strongly valuing fertility. In New Caledonia, the synthetic fertility index is 2.2 children per woman (Direction des Affaires Sanitaires et 
Sociales, 2007), but this index does not reflect the situation in each community. Indeed data collected in this New Caledonian study showed large differences: Kanak women of 40 years of age or older had on average 4.8 children (compared to 3.8 for Polynesian women and 2.2 for European women and those from other communities).

The result on the relationship between CSA and contraception among Kanak women echoes a recent study on intimate partner violence carried out in New Zealand: although refusal of contraception by partners was significantly more important among women who had previously experienced domestic abuse, these women were also more likely than other women to have already used contraception (Fanslow, Whitehead, Silva, \& Robinson, 2008). It could be that Kanak women victims of CSA, who are also more at risk of adult sexual violence, distance themselves from the reproductive social norm of their community and use medically proven forms of contraception which they can control more frequently than other Kanak women.

However, this assumption is not entirely consistent with the lack of association between CSA and abortion in the Kanak women. Several past studies have reported an association between abortion and a history of sexual abuse (Russo \& Denious, 2001; Wingood \& DiClemente, 1997), as observed here in non-Kanak women. In the Kanak community, we also observed that a high level of education increased the likelihood of abortion. These findings suggest problems in the accessibility of abortion, with poor access among uneducated Kanak women, who represent a large majority of the Kanak group and who live far from the urban aera where all abortion clinics are located. Further analysis shows that among Kanak women who had an unintented pregnancy, $18 \%$ wishing an abortion was unable to obtain one, compared to $4 \%$ of non-Kanak women in the same situation.

\section{Conclusion}


This study shows that in all ethnic communities of New Caledonia, a history of child sexual abuse is not rare among women. The findings also shed light on the long term consequences of CSA in women. However, the comparison between indigenous Kanak women and other New Caledonian women suggests that the effect of CSA may differ according to ethnic membership and subsequent social stratification and gender norms. It seems all the more important to underline the extent and the impact of CSA since it was previously unrecognized: more than half (54\%) of Kanak women and 38\% of non-Kanak women who declared having suffered CSA before the age of 15 in the current survey had never disclosed their experience.

The results suggest a range of implications for clinical practice and prevention programs. Sexual risk-taking behavior and violence appear to be multidimensional public health concerns, calling for comprehensive programs that include awareness campaigns, education targeting both the male and female population, and care. In a country where distinct cultural contexts and sets of social features exist, appropriate prevention programs on violence and sexual health using diversified indicators to match the cultural and social heterogeneity are needed. Anthropological studies could help to further understand this issue. Interventions must address the complex factors contributing to a long-lasting alteration in the capacity of women to manage their sexuality. Since early sexual violence often remains a secret, a possible history of violence should be taken into account when assessing individual needs of women with sexual-health related problems. More generally, efforts to break the silence around violence against girls and establish a stronger foundation are required in New Caledonia.

\section{References}


Anderson, I., Crengle, S., Kamaka, M., Chen, T.-H., Palafox, N., \& Jackson-Pulver, L. (2006). Indigenous health in Australia, New Zealand, and the Pacific. The Lancet, 367(9524), $1775-1785$.

Anderson, P., \& Wild, R. (2007). Ampe Akelyernemane Meke Mekarle. Report of the Northern Territory Board of Inquiry into the Protection of Aboriginal Children from Sexual Abuse Darwin: Nothern Territory Governement.

Australian Bureau of Statistics. (2006). Personal Safety Survey 2005. Canberra.

Bajos, N., \& Bozon, M. (2008). Les violences sexuelles en France : quand la parole se libère. Population et sociétés, 445, 1-4.

Barny, S. (2001). Etude sur les grossesses peu ou pas suivies en Nouvelle-Calédonie. Bulletin Médical Calédonien et Polynésien, 23, 14-16.

Beitchman, J. H., Zucker, K. J., Hood, J. E., DaCosta, G. A., Akman, D., \& Cassavia, E. (1992). A review of the long-term effects of child sexual abuse. Child Abuse \& Neglect, 16(1), 101-118.

Berman, A. (2005). The law on gender parity in politics in France and New Caledonia: a window into the future or more of the same? Oxford University Comparative Law Forum 2. Berman, A. (2006). Kanak women and the colonial process. International Journal of Law in Context, 2(1), 11-36.

Bougerol, C., \& Salomon, C. (1998). Représentations du sida et gestion du risque chez les femmes Kanakes de Nouvelle-Calédonie. Paris: Agence Nationale de la Santé et de la Recherche Médicale.

Boyer, D., \& Fine, D. (1992). Sexual abuse as a factor in adolescent pregnancy and child maltreatment. Family Planning Perspectives, 24(1), 4-11, 19. 
Bramley, D., Hebert, P., Tuzzio, L., \& Chassin, M. (2005). Disparities in Indigenous Health: A Cross-Country Comparison Between New Zealand and the United States American Journal of Public Health, 95(5), 844-850.

Dietz, P. M., Spitz, A. M., Anda, R. F., Williamson, D. F., McMahon, P. M., Santelli, J. S., Nordenberg, D.F., Felitti, V.J., \& Kendrick, J.S. (1999). Unintended pregnancy among adult women exposed to abuse or household dysfunction during their childhood. The Journal of the American Medical Association, 282(14), 1359-1364.

Direction des Affaires Sanitaires et Sociales. (2007). Situation sanitaire pour l'année 2007. Nouméa: DASS.

Fanslow, J.L., Whitehead, A., Silva, M., \& Robinson, E.M. (2008). Contraceptive use and associations with intimate partner violence among a population-based sample of New Zealand women. The Australian and New Zealand Journal of Obstetrics and Gynaecology 48(1), 8389.

Fanslow, J. L., Robinson, E. M., Crengle, S., \& Perese, L. (2007). Prevalence of child sexual abuse reported by a cross-sectional sample of New Zealand women. Child Abuse \& Neglect, 31(9), 935-945.

Fergusson, D. M., Horwood, L. J., \& Lynskey, M. T. (1997). Childhood sexual abuse, adolescent sexual behaviors and sexual revictimization. Child Abuse \& Neglect, 21(8), 789803.

Fleming, J., Mullen, P. E., Sibthorpe, B., \& Bammer, G. (1999). The long-term impact of childhood sexual abuse in Australian women. Child Abuse \& Neglect, 23(2), 145-159.

Garcia-Moreno, C., Jansen, H. A. F. M., Ellsberg, M., Heise, L., \& Watts, C. (2005). WHO multi-country study on women's health and domestic violence against women: initial results on prevalence, health outcomes and women's responses. Geneva: Worlds Health Organization. 
Guillonneau, M., \& Kensey, A. (1999). Les détenus outre-mer Paris: Ministère de la justice. Hamelin, C. (2000). Les gens de Nouméa. Mutations et permanences en milieu urbain. In A. Bensa \& I. Leblic (Eds.), En pays kanak. Ethnologie, linguistique, histoire, archéologie en Nouvelle-Calédonie (pp. 339-354). Paris: Editions de la Maison des sciences de l'homme. Hamelin, C., Salomon, C., Sitta, R., Gueguen, A., Cyr, D., \& Lert, F. (2009). Childhood sexual abuse and adult binge drinking among Kanak women in New Caledonia. Social Science \& Medicine, 68(7), 1247-1253.

Heise, L., Ellsberg, M., \& Gottmoeller, M. (2002). A global overview of gender-based violence. International Journal of Gynecology \& Obstetrics, 78(Suppl. 1), S5-S14.

Hillis, S. D., Anda, R. F., Felitti, V. J., Nordenberg, D., \& Marchbanks, P. A. (2000). Adverse childhood experiences and sexually transmitted diseases in men and women: a retrospective study. Pediatrics, 106(1), E11.

Institut de la statistique et des études économiques. (2007). Résultats recensement de la population 2004 ( $\nleftarrow$ http://www.isee.nc/recenspop/rpresultats2004nc.html.)

Institut Territorial de la Statistique et des Etudes Economiques. (2001). Bilan démographique au seuil des années 2000. La population calédonienne au seuil des années 2000. Nouméa:

\section{ITSEE.}

Koss, M. P., Yuan, N. P., Dightman, D., Prince, R. J., Polacca, M., Sanderson, B. \& Goldman, D. (2003). Adverse Childhood Exposures and Alcohol Dependance Among Seven Native American Tribes. American Journal of Preventive Medicine, 25(3), 238-244.

Kunitz, S. J., Levy, J. E., McCloskey, J., \& Gabriel, K. R. (1998). Alcohol dependence and domestic violence as sequelae of abuse and conduct disorder in childhood. Child Abuse \& Neglect, 22(11), 1079-1091. 
Libby, A. M., Orton, H. D., Novins, D. K., Spicer, P., Buchwald, D., Beals, J., \& Manson, S.M. (2004). Childhood Physical and Sexual Abuse and Subsequent Alcohol and Drug Use Disorders in Two American-Indian Tribes. Journal of Studies on Alcohol, 65(1), 74-83.

Littleton, H., Breitkopf, C. R., \& Berenson, A. (2007). Sexual and physical abuse history and adult sexual risk behaviors: relationships among women and potential mediators. Child Abuse \& Neglect, 31(7), 757-768.

Loeb, T. B., Williams, J. K., Carmona, J. V., Rivkin, I., Wyatt, G. E., Chin, D., \& AsuanO'Brien, A. (2002). Child sexual abuse: associations with the sexual functioning of adolescents and adults. Annual Review of Sex Research, 13, 307-345.

Maman, S., Campbell, J., Sweat, M. D., \& Gielen, A. C. (2000). The intersections of HIV and violence: directions for future research and interventions. Social Science \& Medicine, 50(4), 459-478.

Merle, I. (1995). Experiences coloniales : La Nouvelle-Calédonie, 1853-1920. Paris: Belin. Molitor, F., Ruiz, J., Klausner, J., \& McFarland, W. (2000). History of forced sex in association with drug use and sexual HIV risk behaviors, infection with STDs, and diagnostic medical care: Results from the Young Women Survey. Journal of Interpersonal Violence, 15(3), 262-278.

Mullen, P. E., Martin, J. L., Anderson, J. C., Romans, S. E., \& Herbison, G. P. (1996). The long-term impact of the physical, emotional, and sexual abuse of children: a community study. Child Abuse \& Neglect, 20(1), 7-21.

Parillo, K. M., Freeman, R. C., Collier, K., \& Young, P. (2001). Association between early sexual abuse and adult HIV-risky sexual behaviors among community-recruited women. Child Abuse \& Neglect, 25(3), 335-346. 
Pereda, N., Guilera, G., Forns, M., \& Gomez-Benito, J. (2009). The prevalence of child sexual abuse in community and students samples: A meta-analysis. Chinical Psychology Review, 29(4), 328-338.

Petrak, J., Byrne, A., \& Baker, M. (2000). The association between abuse in childhood and STD/HIV risk behaviours in female genitourinary (GU) clinic attendees. Sexually Transmitted Infections, 76(6), 457-461.

Russo, N. F., \& Denious, J. E. (2001). Violence in the Lives of Women Having Abortions: Implications for Practice and Public Policy. Professional Psychology, Research and Practice, 32(2), 142-150.

Salaün, M. (2009). From "primitive mentality" to "clash of cultures": stereotypes and indigenous underachievement in New Caledonian schools. Intercultural Education, 20 (3), 231-241.

Salomon, C. (1998). La personne et le genre au centre nord de la Grande Terre (NouvelleCalédonie). Gradhiva, 23, 81-100.

Salomon, C. (2002). Obligatory Maternity and Diminished Reproductive Autonomy in A'jië Paicî Kanak Societies. In V. Lukere \& M. Jolly (Eds.), Birthing in the Pacific: Beyond Tradition and Modernity? (pp. 79-99). Honolulu: University of Hawai'i Press.

Salomon, C., \& Hamelin, C. (2008). Challenging Violence: Kanak Women Renegotiating Gender Relations in New Caledonia. The Asia Pacific Journal of Anthropology, 9(1), 29-46. Salomon, C., Hamelin, C., Goldberg, P., Sitta, R., Cyr, D., \& Goldberg, M. (2003). HIV protection and screening in women in New Caledonia. Pacific Health Dialog, 10(2), 10-15. Secretariat of the Pacific Community. (2003). The Samoa family health and safety study. Noumea, New Caledonia. 
Stanley, J., Kovacs, K., Tomison, A., \& Cripps, K. (2002). Child Abuse and Family Violence in Aboriginal Communities - Exploring Child Sexual Abuse in Wester Australia. Melbourne: National Child Protection Clearinghouse - Australian Institue of Family Studies.

Steel, J. L., \& Herlitz, C. A. (2005). The association between childhood and adolescent sexual abuse and proxies for sexual risk behavior: a random sample of the general population of Sweden. Child Abuse \& Neglect, 29(10), 1141-1153.

Taft, A. J., Watson, L. F., \& Lee, C. (2004). Violence against young Australian women and association with reproductive events: a cross sectional analysis of a national population sample. Australian and New Zealand Journal of Public Health, 28(4), 324-329.

Testa, M., VanZile-Tamsen, C., \& Livingston, J. A. (2005). Childhood sexual abuse, relationship satisfaction, and sexual risk taking in a community sample of women. Journal of Consulting and Clinical Psychology, 73(6), 1116-1124.

Watts, C., Heise, L., Ellsberg, M., \& Garcia-Moreno, C. (2001). Putting women first: Ethical and safety recommandations for research on domestic violence against women. Geneva: World Health Organisation.

Watts, C., \& Zimmerman, C. (2002). Violence against women: global scope and magnitude. The Lancet, 359(9313), 1232-1237.

Wellings, K., Collumbien, M., Slaymaker, E., Singh, S., Hodges, Z., Patel, D., \& Bajos, N. (2006). Sexual behaviour in context: a global perspective. The Lancet, 368(9548), 1706-1728. Williams, L. M., Siegel, J. A., \& Pomeroy, J. J. (2000). Validity of women's self-reports of documented child sexual abuse. In A. Stone \& J. S. Turkkan (Eds.), The science of selfreport: Implications for research and practice (pp. 211-226). Mahwah: Lawrence Erlbaum. Wingood, G. M., \& DiClemente, R. J. (1997). Child sexual abuse, HIV sexual risk, and gender relations of African-American women. American Journal of Preventive Medicine, 13(5), 380-384. 
Young, T. K., \& Katz, A. (1998). Survivors of sexual abuse: clinical, lifestyle and reproductive consequences. Canadian Medical Association Journal, 159(4), 329-334. Yuan, N. P., Koss, M. P., Polacca, M., \& Goldman, D. (2006). Risk factors for physical assault and rape among six Native American tribes. Journal of Interpersonal Violence, 21(12), 1566-1590. 
Table 3

Childhood sexual abuse and sexual health outcomes in adulthood among Kanak $(n=329)$ and non-Kanak women $(n=436)$. Crude and adjusted odds ratios.

\begin{tabular}{|c|c|c|c|c|c|c|c|c|}
\hline & \multicolumn{4}{|c|}{ Failure to use modern contraception ${ }^{a}$} & \multicolumn{4}{|c|}{ Abortion } \\
\hline & \multicolumn{2}{|c|}{ Kanak women } & \multicolumn{2}{|c|}{ non-Kanak women } & \multicolumn{2}{|c|}{ Kanak women } & \multicolumn{2}{|c|}{ non-Kanak women } \\
\hline & $\begin{array}{c}\text { Unadjusted OR } \\
\text { (and 95\% CI) }\end{array}$ & $\begin{array}{c}\begin{array}{c}\text { Mutually } \\
\text { adjusted OR } \\
\text { (and 95\%CI) }\end{array} \\
\end{array}$ & $\begin{array}{l}\text { Unadjusted OR } \\
\text { (and 95\% CI) }\end{array}$ & $\begin{array}{c}\text { Mutually } \\
\text { adjusted OR } \\
\text { (and 95\%CI) }\end{array}$ & $\begin{array}{c}\text { Unadjusted OR } \\
\text { (and 95\% }\end{array}$ & $\begin{array}{c}\begin{array}{c}\text { Mutually } \\
\text { adjusted OR } \\
\text { (and 95\%CI) }\end{array} \\
\end{array}$ & $\begin{array}{c}\text { Unadjusted OR } \\
\text { (and 95\% CI) }\end{array}$ & $\begin{array}{c}\text { Mutually } \\
\text { adjusted OR } \\
\text { (and 95\%CI) }\end{array}$ \\
\hline \multicolumn{9}{|l|}{ Childhood sexual abuse } \\
\hline No & 1 & 1 & & 1 & 1 & 1 & & 1 \\
\hline Yes & $\mathbf{0 . 2}(0.06-0.8)$ & $0.2(0.07-0.8)$ & $1.2(0.62 .4)$ & $1.2(0.5-2.7)$ & $1.8(0.6-5.0)$ & $1.4(0.5-4.4)$ & $2.3(0.9-6.2)$ & $3.1(1.1-8.8)$ \\
\hline \multicolumn{9}{|l|}{ Age } \\
\hline $18-25$ years & $0.6(0.3-1.2)$ & $0.4(0.2-1.0)$ & $1.4(0.6-3.2)$ & $1.1(0.4-3.1)$ & $6.1(1.7-21.7)$ & $2.9(0.7-12.3)$ & $8.6(1.8-41.0)$ & $11.7(2.1-65.3)$ \\
\hline $26-37$ years & $0.5(0.2-1.0)$ & $0.4(0.2-0.9)$ & $1.8(0.9-3.6)$ & $1.9(0.9-4.0)$ & $2.6(0.7-10.0)$ & $2.2(0.6-8.9)$ & $3.8(0.8-17.5)$ & $4.0(0.9-18.6)$ \\
\hline $38-49$ years & 1 & 1 & 1 & 1 & 1 & 1 & 1 & 1 \\
\hline \multicolumn{9}{|l|}{ Marital status } \\
\hline Married or cohabiting & 1 & 1 & 1 & 1 & 1 & 1 & 1 & 1 \\
\hline $\begin{array}{l}\text { Stable partner, not } \\
\text { cohabiting } \\
\text { No stable partner during }\end{array}$ & $1.3(0.7-2.5)$ & $1.3(0.6-2.7)$ & $0.5(0.2-1.5)$ & $0.7(0.2-2.2)$ & $3.1(1.3-7.3)$ & $2.1(0.8-5.4)$ & $3.2(1.1-9.3)$ & $2.5(0.8-7.9)$ \\
\hline the year & $2.2(0.8-5.8)$ & $2.0(0.7-5.8)$ & $3.9(1.9-8.0)$ & $5.4(2.4-12.1)$ & $2.4(0.6-9.2)$ & $1.7(0.4-7.1)$ & $2.8(0.9-9.0)$ & $2.3(0.7-7.7)$ \\
\hline \multicolumn{9}{|l|}{ Educational level } \\
\hline None or Elementary & $1.1(0.5-2.9)$ & $0.6(0.2-1.8)$ & $4.9(2.4-9.9)$ & $4.5(2.0-10.1)$ & $0.2(0.1-0.5)$ & $0.2(0.07-0.9)$ & $1.6(0.5-5.1)$ & $3.8(1.1-14.3)$ \\
\hline$<$ baccalaureate & $0.9(0.4-2.3)$ & $0.7(0.2-1.9)$ & $2.4(1.2-4.9)$ & $2.4(1.1-5.2)$ & $0.3(0.1-0.9)$ & $0.3(0.1-0.9)$ & $2.1(0.7-5.9)$ & $3.1(1.0-9.2)$ \\
\hline Baccalaureate or higher & 1 & 1 & 1 & 1 & 1 & 1 & 1 & 1 \\
\hline \multicolumn{9}{|l|}{ Personal income } \\
\hline$\leq 335$ Euros/month & $1.8(1.0-3.4)$ & $2.1(1.1-4.1)$ & $3.1(1.8-5.4)$ & $2.7(1.4-5.3)$ & $1.3(0.6-2.9)$ & $1.7(0.6-4.5)$ & $1.3(0.5-3.2)$ & $0.6(0.2-1.7)$ \\
\hline$>335$ Euros/month & 1 & 1 & 1 & 1 & 1 & 1 & 1 & 1 \\
\hline
\end{tabular}


Tableau 3 (continued)

\begin{tabular}{c}
\hline $\begin{array}{c}\text { Sexually Transmitted } \\
\text { Infection }\end{array}$ \\
Kanak women \\
$\begin{array}{c}\text { Mutually } \\
\text { adjusted OR } \\
\text { (and 95\%CI) }\end{array}$ \\
$\begin{array}{c}\text { Unadjusted OR } \\
\text { (and 95\%CI) }\end{array}$
\end{tabular}

\begin{tabular}{|c|c|c|}
\hline \multicolumn{3}{|l|}{ Childhood sexual abuse } \\
\hline No & 1 & 1 \\
\hline Yes & $4.7(1.7-12.5)$ & $3.8(1.3-10.9)$ \\
\hline \multicolumn{3}{|l|}{ Age } \\
\hline $18-25$ years & $2.1(0.7-5.8)$ & $2.6(0.7-9.6)$ \\
\hline $26-37$ years & $0.4(0.1-1.7)$ & $0.5(0.1-1.9)$ \\
\hline 38-49 years & 1 & 1 \\
\hline \multicolumn{3}{|l|}{ Marital status } \\
\hline Married or cohabiting & 1 & 1 \\
\hline $\begin{array}{l}\text { Stable partner, not } \\
\text { cohabiting } \\
\text { No stable partner during the }\end{array}$ & $1.2(0.4-3.4)$ & $0.9(0.3-2.9)$ \\
\hline & $0.7(0.1-5.4)$ & $0.5(0.05-4.3)$ \\
\hline \multicolumn{3}{|l|}{ Educational level } \\
\hline None or Elementary & $1.3(0.3-6.0)$ & $2.7(0.5-16.0)$ \\
\hline$<$ baccalaureate & $0.9(0.2-4.5)$ & $1.5(0.2-8.9)$ \\
\hline Baccalaureate or higher & 1 & 1 \\
\hline \multicolumn{3}{|l|}{ Personal income } \\
\hline$\leq 335$ Euros/month & $1.1(0.4-2.8)$ & $0.8(0.3-2.2)$ \\
\hline > 335 Euros/month & 1 & 1 \\
\hline
\end{tabular}


Undesired sexual intercourse

\begin{tabular}{|c|c|c|c|c|c|c|c|c|}
\hline & \multicolumn{2}{|c|}{ Kanak women } & \multicolumn{2}{|c|}{ non-Kanak women } & \multicolumn{2}{|c|}{ Kanak women } & \multicolumn{2}{|c|}{ non-Kanak women } \\
\hline & $\begin{array}{c}\text { Unadjusted OR } \\
\text { (and 95\% CI) }\end{array}$ & $\begin{array}{c}\text { Mutually } \\
\text { adjusted OR } \\
\text { (and 95\%CI) }\end{array}$ & $\begin{array}{c}\text { Unadjusted OR } \\
\text { (and 95\% CI) }\end{array}$ & $\begin{array}{c}\text { Mutually } \\
\text { adjusted OR } \\
\text { (and 95\%CI) }\end{array}$ & $\begin{array}{c}\text { Unadjusted OR } \\
\text { (and 95\% CI) }\end{array}$ & $\begin{array}{c}\text { Mutually } \\
\text { adjusted OR } \\
\text { (and 95\%CI) }\end{array}$ & $\begin{array}{c}\text { Unadjusted OR } \\
\text { (and 95\% CI) }\end{array}$ & $\begin{array}{c}\text { Mutually } \\
\text { adjusted OR } \\
\text { (and 95\%CI) }\end{array}$ \\
\hline \multicolumn{9}{|l|}{ Childhood sexual abuse } \\
\hline No & 1 & 1 & 1 & 1 & 1 & 1 & 1 & 1 \\
\hline Yes & $2.6(1.3-5.1)$ & $3.4(1.6-7.2)$ & $1.0(0.5-2.0)$ & $1.2(0.6-2.5)$ & $4.3(2.1-8.8)$ & $5.2(2.4-11.1)$ & $1.9(0.6-6.0)$ & $2.6(0.7-9.0)$ \\
\hline \multicolumn{9}{|l|}{ Age } \\
\hline $18-25$ years & $0.4(0.2-0.7)$ & $0.4(0.2-0.8)$ & $0.5(0.2-1.1)$ & $0.9(0.3-2.3)$ & $1.3(0.6-2.7)$ & $1.0(0.4-2.6)$ & $5.0(1.3-19.4)$ & $2.8(0.5-14.2)$ \\
\hline 26-37 years & $1.1(0.7-1.9)$ & $1.2(0.7-2.1)$ & $1.4(0.8-2.4)$ & $1.6(0.9-2.9)$ & $1.5(0.7-2.9)$ & $1.5(0.7-2.1)$ & $1.3(0.3-5.5)$ & $1.2(0.3-5.3)$ \\
\hline $38-49$ years & 1 & 1 & 1 & 1 & 1 & 1 & 1 & 1 \\
\hline \multicolumn{9}{|l|}{ Marital status } \\
\hline Married or cohabiting & 1 & 1 & 1 & 1 & 1 & 1 & 1 & 1 \\
\hline $\begin{array}{l}\text { Stable partner, not } \\
\text { cohabiting } \\
\text { No stable partner during }\end{array}$ & $0.4(0.2-0.7)$ & $0.6(0.3-1.1)$ & $0.5(0.2-1.3)$ & $0.7(0.3-2.0)$ & $1.3(0.7-2.5)$ & $1.6(0.8-3.4)$ & $3.2(0.9-10.7)$ & $2.7(0.7-10.6)$ \\
\hline the year & $0.5(0.2-1.3)$ & $0.7(0.2-2.0)$ & $0.6(0.2-1.5)$ & $0.7(0.2-1.9)$ & $0.6(0.2-2.3)$ & $0.8(0.2-3.0)$ & $2.7(0.7-10.1)$ & $2.3(0.5-9.6)$ \\
\hline \multicolumn{9}{|l|}{ Educational level } \\
\hline None or Elementary & $1.4(0.6-3.1)$ & $1.0(0.4-2.6)$ & $3.6(1.9-6.7)$ & $3.9(2.0-7.7)$ & $2.7(0.8-9.5)$ & $0.8(0.4-1.6)$ & $2.0(0.5-7.6)$ & $2.6(0.6-12.4)$ \\
\hline$<$ baccalaureate & $1.0(0.4-2.3)$ & $0.8(0.3-2.1)$ & $1.6(0.9-3.1)$ & $1.7(0.9-3.3)$ & $2.7(0.8-9.4)$ & $0.3(0.07-1.1)$ & $2.5(0.7-8.5)$ & $2.7(0.7-9.8)$ \\
\hline Baccalaureate or higher & 1 & 1 & 1 & 1 & 1 & 1 & 1 & 1 \\
\hline \multicolumn{9}{|l|}{ Personal income } \\
\hline$\leq 335$ Euros/month & $0.8(0.5-1.2)$ & $1.0(0.6-1.7)$ & $0.8(0.4-1.4)$ & $0.6(0.3-1.2)$ & $1.4(0.8-2.5)$ & $1.3(0.7-2.5)$ & $7.0(2.4-20.3)$ & $4.4(1.4-14.4)$ \\
\hline > 335 Euros/month & 1 & 1 & 1 & 1 & 1 & 1 & 1 & 1 \\
\hline
\end{tabular}


